\title{
DETERMINATION OF KINETIC PARAMETERS IN A PILOT SCALE BNR SYSTEM TREATING MUNICIPAL WASTEWATER
}

\author{
A.G. KAPAGIANNIDIS* \\ E. VAIOPOULOU \\ A. AIVASIDIS
}

Selected from papers presented in $9^{\text {th }}$ International Conference on Environmental

Science and Technology (9CEST2005)

1-3 September 2005, Rhodes island, Greece

\author{
Department of Environmental Engineering, \\ Democritus University of Thrace, \\ Vas. Sofias 12, Xanthi, 67100, Greece
}

to whom all correspondence should be addressed

Tel/Fax: +30-25410-79376

e-mail: akapagia@env.duth.gr

\begin{abstract}
Kinetics for the biological processes of nitrification, denitrification and carbon oxidation were studied in the aerobic and anoxic phases of a pilot scale Biological Nutrient Removal (BNR) plant treating municipal wastewater. The configuration of the treating system is based on the combination of the UCT (University of Cape Town) design and the step feeding process in a
\end{abstract} cascade denitrification.

In order to study the process kinetics and to obtain reliable values for the investigated kinetic parameters batch experiments were performed. For this purpose, continuous feeding of the treating system was interrupted for a given period of time and the pilot plant was turned into a batch mode of operation. Thereafter, addition of $\mathrm{NO}_{3}{ }^{-} \mathrm{N}$ and $\mathrm{NH}_{4}{ }^{+}-\mathrm{N}$ into the anoxic and aerobic compartments of the treating plant, respectively, followed, whereas adequate initial concentration of a carbon source (municipal wastewater or synthetic substrate) was ensured in the mixed liquor. Experimental data indicated that the examined biological processes followed saturation kinetics.

The maximum specific denitrification rate, $\mathrm{q}_{\mathrm{DN}, \max }$, was found to obtain values, depending on the type of the carbon source, between 0,045 and $0,390 \mathrm{gNO}_{3}{ }^{-} \mathrm{N} /\left(\mathrm{gX}_{\mathrm{HET}} \cdot \mathrm{d}\right)$, whereas the extremely low value of the half saturation constant for the denitrification process $\left(\mathrm{K}_{\mathrm{m}, \mathrm{NO}-\mathrm{N}}<<\right.$ $1 \mathrm{mgN} / \mathrm{l})$ indicated its description by zero order kinetics. The maximum specific nitrification rate, $\mathrm{q}_{\mathrm{N}, \max }$, was determined to vary in a narrow frame, between 1,28 and $1,60 \mathrm{gNH}_{4}{ }^{+}-$

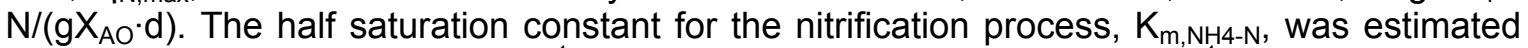
graphically at $3,1-6,1 \mathrm{gNH}_{4}{ }^{+}-\mathrm{N} \mathrm{I}^{-1}$, corresponding to $62-122 \mu \mathrm{gNH}_{3}-\mathrm{N} \mathrm{I}^{-1}$. These values are considered to be in good agreement with the literature.

The determination of kinetic parameters can be considered as a useful tool for the process design, operation and improvement of wastewater treatment plants. Furthermore, the study of the biological process kinetics contributes to the better understanding and outline of the complicated biological processes that contemporarily take place within the various phases of BNR wastewater treatment plants.

KEYWORDS: municipal wastewater treatment, BNR, batch experiments, nitrification denitrification kinetics, maximum specific (de)nitrification rate, half saturation constants

\section{INTRODUCTION}

Over the last decades several wastewater treatment methods have been developed and modified with a view to limiting discharge to the environment of nitrogenous and phosphorous nutrients that are the main factors responsible for the eutrophication of surface water. Among them, biological nutrient removal (BNR) processes have been recognized as the most suitable treatment methods from environmental as well as economical point of view. 
Depending on the configuration of a single treatment plant, its operation can involve nitrogen removal, through Nitrification - Denitrification (ND), or phosphorus removal, through Enhanced Biological Phosphorus Removal (EBPR) process, in conjuction with carbon oxidation $\left(\mathrm{BOD}_{5}, \mathrm{COD}\right)$. However, activated sludge treatment plants are currently designed to combine Carbon $(\mathrm{C})$, Nitrogen $(\mathrm{N})$ and Phosphorus $(\mathrm{P})$ removal, in an integrated tertiary wastewater treatment system (Nitrification - Denitrification and Biological Enhanced Phosphorus Removal process, NDBEPR). In order to achieve simultaneous $\mathrm{C}, \mathrm{N}$ and $\mathrm{P}$ removal in a treatment plant a broad frame of bacteria species should be utilized. For the growth of the different species, anaerobic, aerobic and anoxic treatment phases are postulated.

During the past, BNR processes have been successfully applied in full scale Wastewater Treatment Plants (WWTP's) proving their practical feasibility. However, the application of such treatment methods is likely to become an arduous task. The causes that can potentially lead to such a situation can be mainly summarized by the following points:

- The (micro)biological basis that sustains BNR processes makes their implementation really sensitive (i.e. to toxic pollutants, intense fluctuations of the influent flow and/or the type of the incoming wastewater e.t.c.).

- The various microorganisms that exist in BNR treatment plants compete one another not only for the use of organic substrate but also for their maintenance under specific operational conditions (i.e. hydraulic residence time, sludge age). Thus, reduction of this competition is necessary in order to achieve adequate efficiency of the plant operation.

- Biological nutrient removal consists of complex biochemical processes related to the different bacteria species that accomplish the carbon, nitrogen and phosphorus removal and also to the relative amounts of compounds, such as nitrate, nitrite and volatile fatty acids, in the mixed liquor within the various treatment phases (anaerobic, anoxic, aerobic). Scientific studies on the processes' biochemistry as well as on the metabolic behaviour of the microorganisms involved, have conducted only during the recent past and, as a result, several topics still have to be clarified.

Obviously, a large number of chemical and biological reactions simultaneously take place in a nutrient removal treatment plant. The reactions' rate exerts a grate influence on the treatment process as well as on the optimum plant's design. The determination of kinetic parameters facilitates the selection of the proper design parameters for a WWTP as well as its optimized operation control. Furthermore, the study of the biological process kinetics contributes to the better understanding of the biological processes that contemporarily take place within the various phases of BNR wastewater treatment plants.

The objective of this study was the determination of kinetic parameters $q_{D N, m a x}, K_{m, N O 3-N}$, related to denitrification, as well as $\mathrm{q}_{\mathrm{N}, \max }, \mathrm{K}_{\mathrm{m}, \mathrm{NH} 4-\mathrm{N}}$, describing nitrification. Discussion on carbon oxidation under aerobic and anoxic conditions is also attempted.

\section{MATERIALS AND METHODS}

A pilot scale BNR plant treating municipal wastewater has been chosen to conduct this study. The configuration of the treating system is based on the combination of the UCT (University of Cape Town) design and the step feeding process in a cascade denitrification for simultaneous carbon, nitrogen and phosphorus removal. A schematic layout of the treating system is presented in Figure 1. It consists of an anaerobic tank followed by a cascade of three identical double-vessels (each one includes an anoxic and an aerobic compartment) and finally of a secondary sedimentation tank (clarifier). After separation in the clarifier, part of the secondary sludge is pumped back as a return sludge to the first anoxic tank and the rest is removed as excess sludge. Air is pumped at the bottom of each of the aerobic compartments according to the diffused aeration method. All tanks (except the clarifier) are gently stirred.

Due to the given plant's configuration, nitrification takes place in the aerobic tanks, denitrification in the anoxic tanks, whereas biological phosphorus removal is achieved by the enrichment of certain bacteria species in the activated sludge, which obtain the selective advantage and grow under alternate anaerobic and aerobic conditions. Table 1 shows the operational volume of each tank, whereas Table 2 demonstrates the basic operational parameters that characterize the plant's operation. 


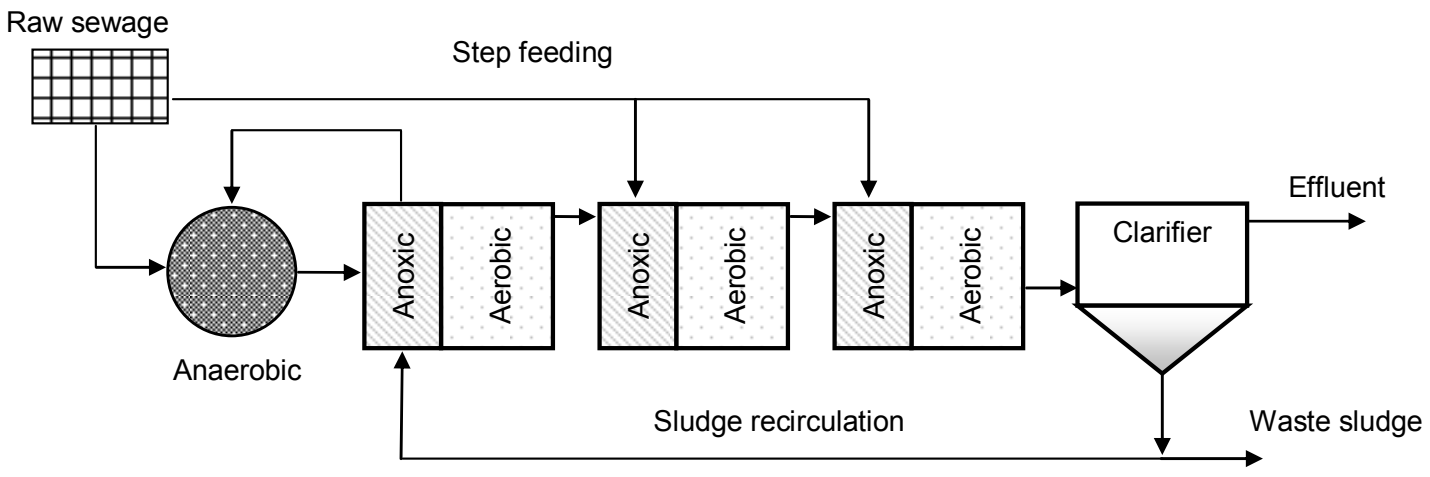

Figure 1. Schematic layout of the pilot scale BNR plant

Table 1. Operational volume for each tank of the pilot plant

\begin{tabular}{|c|c|c|c|c|}
\hline \multicolumn{2}{|c|}{ Tank } & $\begin{array}{l}\text { Operational conditions / } \\
\text { process }\end{array}$ & Tank codename & $\begin{array}{l}\text { Operational } \\
\text { volume } \\
\text { (I) }\end{array}$ \\
\hline \multicolumn{2}{|c|}{ Anaerobic } & Anaerobic & ANAER & 3,5 \\
\hline \multirow{2}{*}{$\begin{array}{l}1^{\text {st }} \text { double } \\
\text { vessel }\end{array}$} & Anoxic & DeNitrification & DN1 & 3,4 \\
\hline & $\begin{array}{l}\text { Aerobic } \\
\text { Compartment }\end{array}$ & Nitrification & N1 & 7,3 \\
\hline \multirow{2}{*}{$\begin{array}{l}2^{\text {nd }} \text { double } \\
\text { vessel }\end{array}$} & Anoxic & DeNitrification & DN2 & 3,4 \\
\hline & $\begin{array}{l}\text { Aerobic } \\
\text { Compartment }\end{array}$ & Nitrification & N2 & 7,3 \\
\hline \multirow{2}{*}{$\begin{array}{l}3^{\text {rd }} \text { double } \\
\text { vessel }\end{array}$} & $\begin{array}{l}\text { Anoxic } \\
\text { Compartment }\end{array}$ & DeNitrification & DN3 & 3,4 \\
\hline & $\begin{array}{l}\text { Aerobic } \\
\text { Compartment }\end{array}$ & Nitrification & N3 & 7,3 \\
\hline \multicolumn{2}{|c|}{ Clarifier } & Settling Tank & ST & 8,3 \\
\hline & & & Total operational volume & 43,9 \\
\hline
\end{tabular}

Table 2. Basic plant operational parameters

\begin{tabular}{|c|c|c|c|}
\hline Operational parameter & Symbol & $\begin{array}{c}\text { Min. } \\
\text { value }\end{array}$ & $\begin{array}{l}\text { Max. } \\
\text { value }\end{array}$ \\
\hline Influent flow & $Q_{F}\left[I h^{-1}\right]$ & 2 & 5 \\
\hline Mean hydraulic residence time & $\mathrm{T}[\mathrm{h}]$ & 9 & 22 \\
\hline Organic loading rate ${ }^{1}$ & $\mathrm{~L}_{\mathrm{BOD} 5}\left[\mathrm{~g} \mathrm{BOD}_{5} \mathrm{~d}^{-1}\right]$ & 8,2 & 38,4 \\
\hline Organic loading rate ${ }^{2}$ & $\mathrm{~L}_{\mathrm{COD}}\left[\mathrm{g} \operatorname{COD} \mathrm{d}^{-1}\right]$ & 11,2 & 70,4 \\
\hline Total Kjeldahl Nitrogen loading & $\mathrm{L}_{T K N}\left[\mathrm{~g} \mathrm{TKN} \mathrm{d}^{-1}\right]$ & 2,2 & 7,5 \\
\hline Ammonia nitrogen loading rate & $\mathrm{L}_{\mathrm{NH} 4-\mathrm{N}}\left[\mathrm{g} \mathrm{NH}_{4}{ }^{+}-\mathrm{N} \mathrm{d}^{-1}\right]$ & 1,5 & 5,9 \\
\hline Phosphorus loading rate & $\mathrm{L}_{\mathrm{PO} 4-\mathrm{P}}\left[\mathrm{g} \mathrm{PO}_{4}{ }^{3-}-\mathrm{P} \mathrm{d}^{-1}\right]$ & 0,1 & 0,54 \\
\hline F/M ratio & $\mathrm{F} / \mathrm{M}\left[\mathrm{g} \mathrm{BOD}{ }_{5}(\mathrm{gX} . \mathrm{d})^{-1}\right]$ & 0,09 & 0,51 \\
\hline Sludge age & $\theta_{\mathrm{C}}[\mathrm{d}]$ & 9,6 & 28,5 \\
\hline
\end{tabular}

In terms of $\mathrm{BOD}_{5}$

${ }^{2}$ In terms of COD

In order to estimate the values of the investigated kinetic parameters the continuous feeding of the treating system was interrupted for a given period of time and the pilot plant was turned into a batch mode of operation, i.e. hydraulic isolation of each single tank. Instant addition of nitrate (of about $30 \mathrm{mg} \mathrm{NO}_{3}{ }^{-} \mathrm{N}^{-1}$ ) and organic substrate (acetate or raw sewage of about 150 $-200 \mathrm{mg} \mathrm{COD}^{-1}$ ) took place directly in the three anoxic compartments. At the same time, ammonia, was added in excess amount $\left(30-40 \mathrm{mg} \mathrm{NH}_{4}{ }^{+}-\mathrm{N} \mathrm{I}^{-1}\right)$ in the aerobic tanks. Also, a 
certain concentration of COD was ensured in these tanks by addition of adequate amount of acetate or municipal wastewater as a carbon source.

Samples of mixed liquor were taken by means of a syringe from each single tank at fixed time intervals and were immediately filtered through a Foldefiltre Type 500AF. The sampling volume can be neglected in comparison with the total tank volume and as a result it does not affect the experimental results. Samples from the anoxic tanks were analyzed for VSS and nitrate, whereas samples withdrawn under aerobic conditions were analyzed for VSS and ammonium nitrogen. All analysis was conducted according to Standard Methods [1]. For analysis of nitrate, $10 \mathrm{ml}$ of the filtrate were taken out and subjected to further filtration through a $0.2 \mu \mathrm{m}$ filter in order to be analyzed on a High Performance Liquid Chromatographer (HPLC) with a conductivity detector. The column was a PRP X-100 $15 \mathrm{~cm}$ long and phydroxybenzoic acid was used as the eluent.

\section{RESULTS AND DISCUSSION \\ Denitrification}

Experimental results of a typical denitrification batch test for the three anoxic tanks of the pilot pant are shown in Figure 2. The specific denitrification rate, $\mathrm{q}_{\mathrm{DN}}\left(\mathrm{gNO}_{3}{ }^{-} \mathrm{N} /\left(\mathrm{g} \mathrm{X}_{\mathrm{HET}} \cdot \mathrm{d}\right)\right)$, is related to the denitrification rate with the following equation:

$$
\frac{d\left(N_{3}-N\right)}{d t}=q_{D N} \cdot X_{H E T}
$$

where $X_{H E T}$ is the heterotrophic biomass expressed in $\mathrm{g} / \mathrm{l}$. Most investigators agree that denitrification follows zero order kinetics with respect to nitrate down to very low nitrite concentrations [2], a fact that is also confirmed by the present research. Two slopes can be observed: initially, a rapid nitrate utilisation rate $(\mathrm{dN} / \mathrm{dt})_{\max }$, which is followed by a lower denitrification rate $(\mathrm{dN} / \mathrm{dt})_{\text {end }}$, that continues until all nitrate is consumed. The first slope reflects the denitrification on the external organic substrate ( $\left.q_{D N, \max }\right)$. As soon as the carbon source is depleted, the denitrification continuous using endogenous matter as the electron donor in a much lower rate $\left(\mathrm{q}_{\mathrm{DN}, \text { end }}\right)$. The results of five repeated tests using two different carbon sources are summarized in Table 3 . These values are considered to be in good agreement with the literature. [3], [4], [5]

Table 3. Values for the specific denitrification rate determined in repeated batch tests

\begin{tabular}{|c|c|c|c|c|c|c|c|}
\hline \multirow{2}{*}{$\begin{array}{l}\text { batch } \\
\text { No. }\end{array}$} & \multirow{2}{*}{$\begin{array}{l}\text { Carbon } \\
\text { source }\end{array}$} & \multicolumn{3}{|c|}{$\begin{array}{c}\mathrm{q}_{\mathrm{DN}, \max } \\
{\left[\mathrm{gNO}_{3}-\mathrm{N} /\left(\mathbf{g X} \mathrm{H}_{\mathrm{HET}} \cdot \mathrm{d}\right)\right]}\end{array}$} & \multicolumn{3}{|c|}{$\begin{array}{c}\mathrm{q}_{\mathrm{DN}, \text { end }} \\
{\left[\mathrm{gNO}_{3}-\mathrm{N} /\left(\mathbf{g X} \mathrm{HET}^{-} \cdot \mathrm{d}\right)\right]}\end{array}$} \\
\hline & & DN1 & DN2 & DN3 & DN1 & DN2 & DN3 \\
\hline 1 & Raw sewage & 0,103 & 0,045 & 0,055 & 0,023 & 0,015 & 0,009 \\
\hline 2 & Raw sewage & 0,072 & 0,089 & 0,057 & 0,037 & 0,017 & 0,020 \\
\hline 3 & Raw sewage & 0,148 & 0,072 & 0,075 & 0,022 & 0,025 & 0,032 \\
\hline 4 & $\mathrm{HAc}$ & 0,240 & 0,082 & 0,077 & 0,063 & - & 0,035 \\
\hline 5 & $\mathrm{HAc}$ & 0,390 & 0,272 & 0,172 & 0,061 & 0,048 & 0,057 \\
\hline
\end{tabular}

The results indicate that denitrification proceeds much faster when acetate is used as an electron donor in comparison with the tests where municipal wastewater was used as a carbon source. This is due to the fact that acetate is a mono - component, easily biodegradable and, therefore, is readily used by the biomass for denitrification. It should be also noted that the highest values for the maximum specific denitrification rate, $q_{D N \text {, max }}$, were observed at the first anoxic tank (DN1). This is probably due to the microbial activity of Denitrifying Phosphorus Accumulating Organisms (DPAOs), which oxidize intracellular 
carbonaceous matter (PHB, PHV), being stored under the precedent anaerobic conditions, using nitrate as the final electron acceptor [6]. This "supplementary" denitrification by DPAOs yields to a favourable total denitrifying activity in the first anoxic tank.

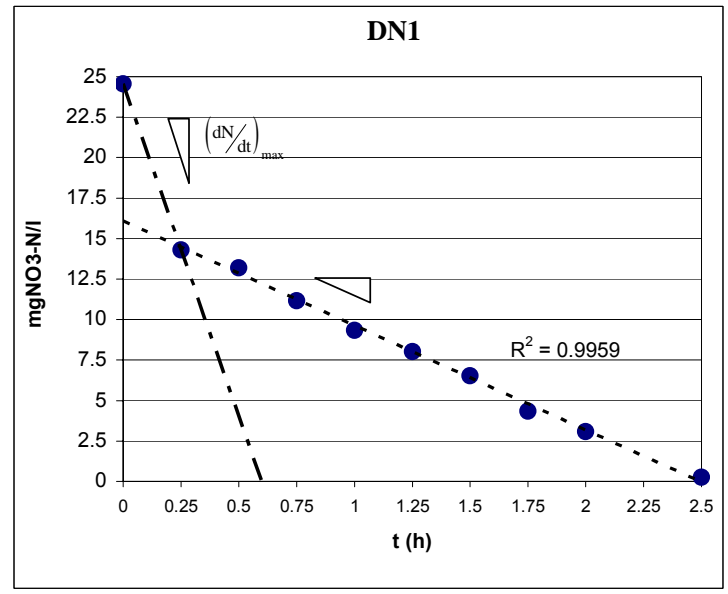

a)

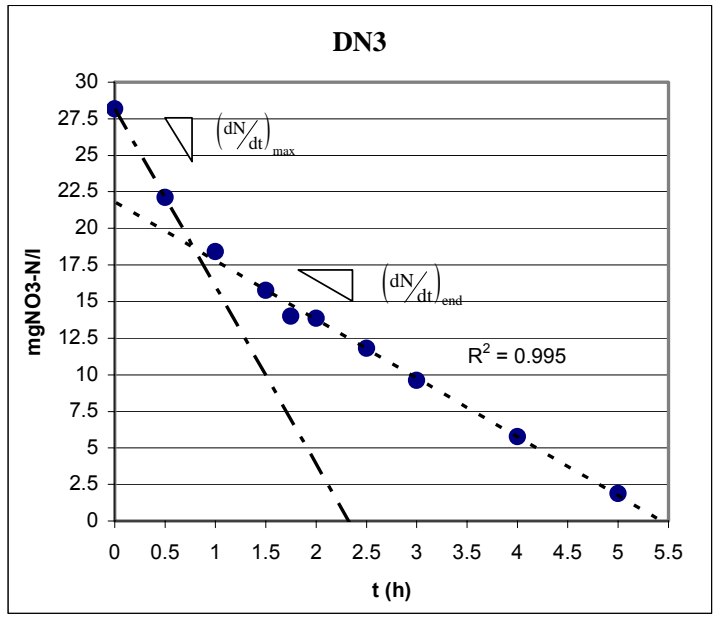

c)

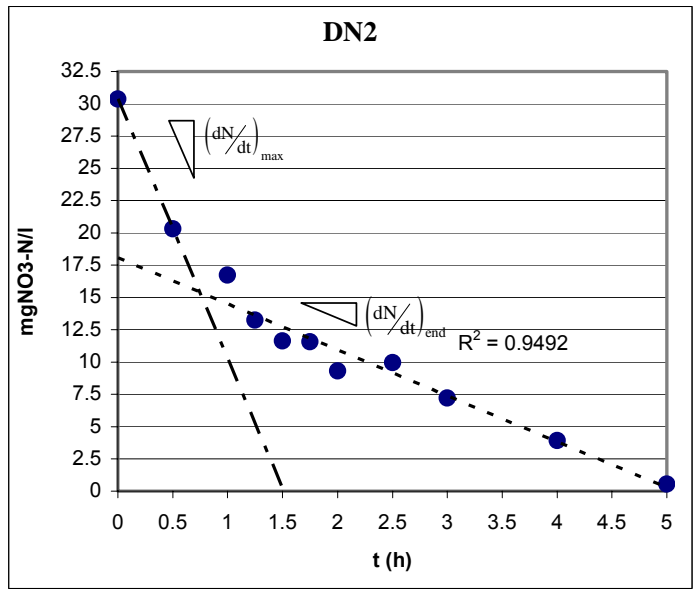

b)

Figure 2. $\mathrm{NO}_{3}^{-}-\mathrm{N}$ profiles of a typical batch test for the a) $1^{\text {st }}$, b) $2^{\text {nd }}$ and c) $3^{\text {rd }}$ anoxic tank (acetate was used as the carbon source)

\section{Nitrification}

The most popular model applied to describe nitrification, providing $\mathrm{O}_{2}$ and $\mathrm{CO}_{2}$ saturation in the medium, is that of Monod [7]:

$q_{N}=q_{N, \max } \frac{S_{\mathrm{NH}_{4}-\mathrm{N}}}{K_{N}+S_{\mathrm{NH}_{4}-\mathrm{N}}}$

where

$\mathrm{q}_{\mathrm{N}}$ : specific nitrification rate $\left[\mathrm{gNH}_{4}{ }^{+}-\mathrm{N}(\mathrm{gX} \mathrm{AO} \cdot \mathrm{d})^{-1}\right]$

$\mathrm{q}_{\mathrm{N}, \text { max }}$ : maximum specific nitrification rate $\left[\mathrm{gNH}_{4}{ }^{+} \mathrm{N} /\left(\mathrm{gX} \mathrm{AO}_{\mathrm{AO}} \cdot \mathrm{d}\right)^{-1}\right]$

$\mathrm{S}_{\mathrm{NH} 4-\mathrm{N}}$ : concentration of ammonium - nitrogen $\left[\mathrm{mgNH}_{4}{ }^{+}-\mathrm{N} \mathrm{I}^{-1}\right]$

$\mathrm{K}_{\mathrm{m}, \mathrm{N}}$ : half saturation constant for ammonium - nitrogen $\left[\mathrm{mgNH}_{4}{ }^{+}-\mathrm{N} \mathrm{I}^{-1}\right.$ ]

$\mathrm{X}_{\mathrm{AO}}$ : concentration of nitrifying biomass $\left[\mathrm{mg} \mathrm{I}^{-1}\right]$

Experimental results of a typical nitrification batch test for the three aerobic tanks of the pilot pant are demonstrated in Figure 3. All diagrams indicate that high $\mathrm{NH}_{4}{ }^{+}-\mathrm{N}$ concentrations ensure the process' description by zero order kinetics. As nitrogen becomes limiting, i.e. $\mathrm{NH}_{4}{ }^{+}-\mathrm{N}$ concentrations below $10 \mathrm{mg} \mathrm{l}{ }^{-1}$, the reaction is being described by a transition between zero and first order kinetics. According to Monod kinetics the substrate concentration for which the process rate becomes equal to the half of its maximum value, $\left(q_{N}=q_{N, \max } / 2\right)$, represents the half saturation constant, $\mathrm{K}_{\mathrm{m}, \mathrm{N}}$. The results of two repeated tests for nitrification 
are summarized in Table 4. These values are considered to be in good agreement with the literature. [8], [9]

Table 4. Values for maximum specific nitrification rates and half saturation constants determined in repeated batch tests

\begin{tabular}{|c|c|c|c|c|c|c|}
\hline \multirow{2}{*}{$\begin{array}{l}\text { batch } \\
\text { No. }\end{array}$} & \multicolumn{3}{|c|}{$\begin{array}{c}q_{\mathrm{N}, \max } \\
{\left[\mathrm{gNH}_{4}{ }^{-}-\mathrm{N} /\left(\mathbf{g X} X_{\mathrm{AO}} \cdot \mathrm{d}\right)\right]}\end{array}$} & \multicolumn{3}{|c|}{$\begin{array}{c}\mathrm{K}_{\mathrm{m}, \mathrm{N}} \\
{\left[\mathrm{mgNH}_{4}^{+}-\mathrm{N} \mathrm{I}^{-1}\right]}\end{array}$} \\
\hline & N1 & N2 & N3 & N1 & N2 & N3 \\
\hline 1 & 1,60 & 1,35 & 1,42 & 4,8 & 4,0 & 3,5 \\
\hline 2 & 1,50 & 1,32 & 1,28 & 6,1 & 3,4 & 3,1 \\
\hline
\end{tabular}

\section{CONCLUSIONS}

Kinetics of nitrification and denitrification processes were investigated in a pilot scale BNR plant treating municipal wastewater. Experimental data was used for determination of kinetic parameters and the following values were found: for denitrification $q_{D N, \max }=0,045-0,148$ $\mathrm{gNO}_{3}{ }^{-} \mathrm{N} /\left(\mathrm{gX}_{\mathrm{HET}} \cdot \mathrm{d}\right)$ when domestic wastewater was used as a carbon source and $\mathrm{q}_{\mathrm{DN}, \max }=$ $0,077-0,390 \mathrm{gNO}_{3}{ }^{-} \mathrm{N} /\left(\mathrm{gX}_{\mathrm{HET}} \cdot \mathrm{d}\right)$ when acetate was the electron donor. The endogenous rate was determined as $\mathrm{q}_{\mathrm{DN}, \text { end }}=0,009-0,037 \mathrm{gNO}_{3}{ }^{-} \mathrm{N} /(\mathrm{gX}$ HET $\cdot d)$. The highest denitrification rates were observed in the first anoxic tank where the operational conditions favor the denitrifying activity of DPAOs. The results confirmed that denitrification is a zero order reaction with respect to nitrate. Nitrification process was found to follow Monod type kinetics. The determined kinetic parameters for nitrification was: $\mathrm{q}_{\mathrm{N} \text {, max }}=1,28-1,6 \mathrm{gNH}_{4}^{+}-\mathrm{N} /(\mathrm{gX}$ AO $\cdot \mathrm{d})$ and $\mathrm{K}_{\mathrm{m}, \mathrm{N}}=3,1-6,1 \mathrm{mgNH}_{4}{ }^{+}-\mathrm{N} \mathrm{I}^{-1}$. These values are in good agreement with the literature.

The determination of kinetic parameters can be considered as a useful tool for the process design, operation and improvement of wastewater treatment plants.

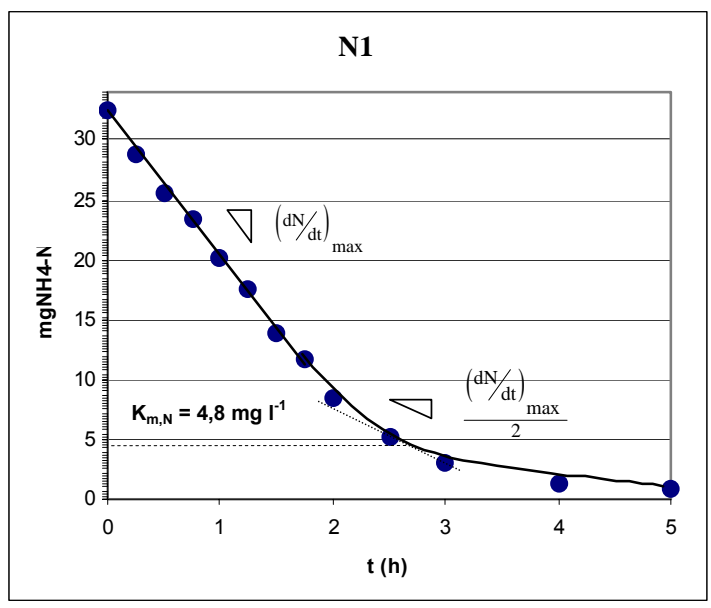

a)

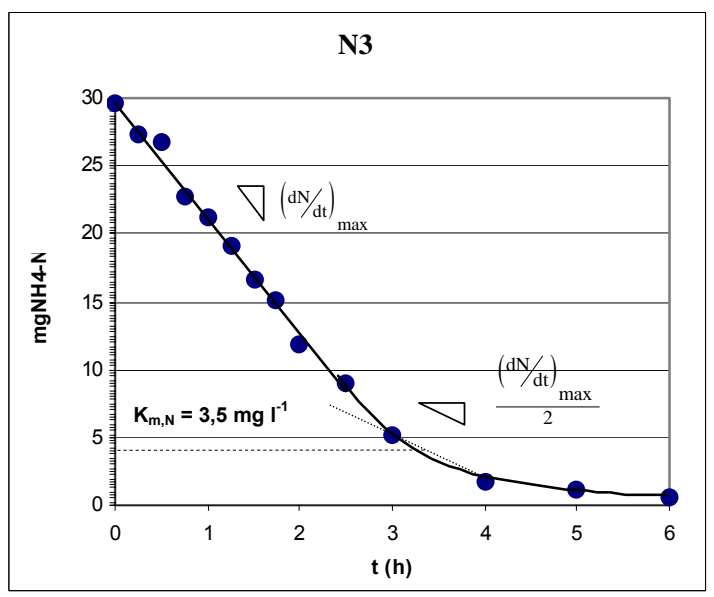

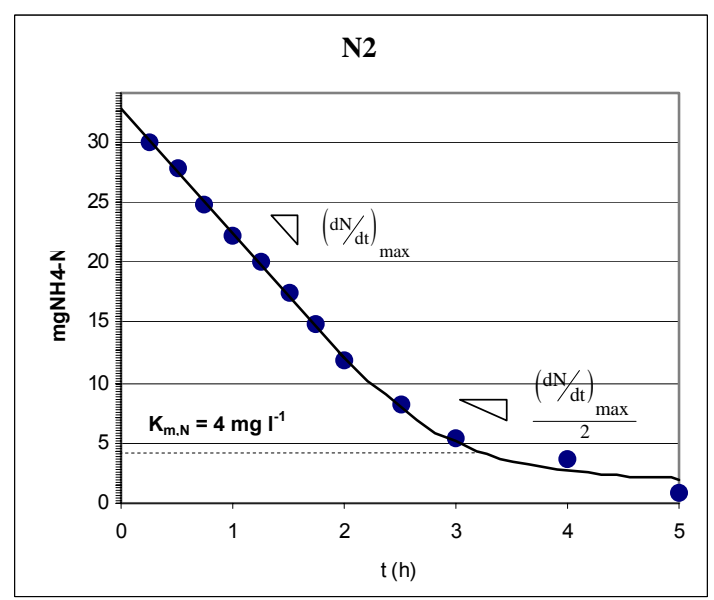

b)

Figure 3. $\mathrm{NH}_{4}{ }^{+}-\mathrm{N}$ profiles of a typical batch test for the a) $1^{\text {st }}$, b) $2^{\text {nd }}$ and c) $3^{\text {rd }}$ aerobic tank 


\section{REFERENCES}

1. APHA, (1998), Standard Methods for the Examination of Water and Wastewater, $20^{\text {th }}$ edn., Washington, D.C.

2. Beccari M., Passino R., Ramadori R. and Tandoi V. (1983), Kinetics of dissimilatory nitrate and nitrite reduction in suspended growth culture J. Water Pollut. Control. Fed., 55, 58 - 64.

3. Carruci A., Ramadori.R., Rossetti S. and Tomei M.C. (1996), "Kinetics of denitrification reactions in single sludge systems" Wat. Res., 30, $51-56$.

4. Henze M. (1989), The ifluence of raw wastewater biomass on activated sludge oxygen respiration rates and denitrification rates Wat. Sci. Tech. 21, $603-607$.

5. Kristensen G.H., Jørgensen P.E. and Henze M. (1992), Characterisation of functional microorganisms groups and substrate in activated sludge and wastewater by AUR, NUR and OUR Wat. Sci. Tech. 25, $43-57$.

6. Barker P.S. and Dold P.L. (1996), Denitrification behaviour in biological excess phosphorus removal activated sludge systems Wat. Res. 30, 769-780

7. Monod J. (1949), The growth of bacterial cultures Ann. Rev. Microbiol. 3, 371 -394.

8. Metcalf \& Eddy, Inc. (1991), Wastewater Engineering: Treatment - Disposal - Reuse, $3^{\text {rd }}$ ed., Mac-Graw-Hill, New York, pp $695-711$.

9. Dinçer A.R. and Kargi F. (2000), Kinetics of sequential nitrification and denitrification processes Enz. Microb.Tech., 27, 37 - 42. 